Review Article

\title{
Rudolf Virchow: Requiem for a Visionary
}

\author{
Julián Rondón Carvajal, ${ }^{1 *}$ Juan Miguel Ruiz Zuluaga ${ }^{2}$ \\ ${ }^{1}$ Doctor and surgeon, Universidad de Antioquia, Colombia \\ ${ }^{2}$ Physician and surgeon, University of Antioquia. Medellin Colombia
}

\begin{abstract}
Rudolf Virchow's scientific legacy to mankind is invaluable. His holistic view of disease allowed him to develop detailed experimental models based on the precepts of cell biology, which is why he is considered the forerunner of modern pathology. Many of his observations were transferred to the clinical setting and are still valid today in different areas of internal medicine. This biographical sketch highlights his main contributions to modern medical practice on the basis of his profound social sensitivity, including the founding of the first German anthropological society.
\end{abstract}

Keywords: History of medicine, Social medicine, Clinical pathology, Medical anthropology, Internal medicine, Medical anthropology

\section{Introduction}

It is healthy to evoke the figure of Rudolf Virchow through this portrait, since he was a champion of Public Health, a branch of medicine that seeks to safeguard human dignity within the dynamics of contemporary societies, based on the satisfaction of fundamental rights, such as food, housing and access to health. Moreover, his altruistic and investigative spirit is worthy of emulation in our medical communities, whatever their work over time.We would also like to mention his deep involvement in state affairs, which made him a true social bulwark. We consider these qualities to be those that the health professional should strive for from the very beginning of his or her university education.

\section{Socio-political context of Prussia in the $19^{\text {th }}$ century}

The Kingdom of Prussia was the last remnant of the Holy Roman Empire. When Prussia fell to Napoleon's forces, the Confederation of the Rhine was created, after the dissolution of which the German Confederation was consolidated in 1815 as a union of 39 states in territories that today would include countries such as Germany, Poland, Hungary, the Czech Republic, among others.Subsequently, the Austro-Prussian War, which ended in 1866, resulted in the victory of the North German Confederation, allowing the unification of the 22 victorious states, with King Wilhelm I as President and Otto von Bismarck as Chancellor. After the Franco-Prussian War ended in 1871, Bavaria and Baden-Württemberg were annexed, creating the German Empire. ${ }^{1}$

Until the end of the $18^{\text {th }}$ century, medicine was still influenced by the classical Greek legacy, through the humoral theory of disease proclaimed by Galen. At the beginning of the $19^{\text {th }}$ century, this approach proved insufficient and some diseases would be explained by the lesion theory, disseminated through the systematic dissection of cadavers in the main European academic cloisters from the mid- $16^{\text {th }}$ century. At the same time, new exploratory techniques were developed in order to find the cause of the disease from semiology, giving rise to experimental medicine, with the French physiologist Claude Bernard and the laboratory diagnostic analysis of body fluids. ${ }^{1,2}$ The fundamental principles of aetiopathogenic theory began to be established in the late 1890s, including concepts such as interaction between micro-organisms with pathogenic potential and the host, as well as the subsequent development of models of infection explained from the postulates of Louis Pasteur in France and later, Robert Koch in Germany, parallel to the development of vaccines based on the principles of passive immunisation put forward by Edward Jenner, the discovery of the in vitro properties of antibiotics and the large-scale implementation of sterilisation processes and basic hygiene measures as effective methods of dealing with the spread of infectious diseases. ${ }^{3,4}$ With Pasteur, the theory of
Quick Response Code:

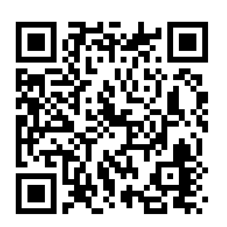

*Corresponding author: Julián Rondón Carvajal, Physician and surgeon, University of Antioquia. Specialist in Internal Medicine, Pontificia Universidad Javeriana. Internist, SURA EPS and IPS Universitaria- Universidad de Antioquia, Medellin Colombia

Received: 24 May, 2021

Published: 02 June, 2021

Citation: Julián RC, Juan MRZ. Rudolf Virchow: Requiem for a Visionary. Curr Inv Cln Med Res. 2021;1(1):1-5. DOI: 10.53902/CICMR.2021.01.000505 
spontaneous generation was refuted by scientific experimentation, and the principle "Omne vivum ex vivo" (All life comes from life) was established, which was the key to the development of the subsequent cell theory. ${ }^{5}$

\section{Early years}

Around 1821, Rudolf Virchow was born in a rural area of Schivelbein, Pomerania (present-day Poland). Born to Lutheran parents, his upbringing was strongly influenced by the Polish culture of this European region. He attended secondary school in Koszalin, which in later years enabled him to become fluent in several languages such as German, French, English, Latin, Polish, Italian, Greek and other Slavic languages. In 1839 he received a scholarship from the Prussian Military Academy to train as an army doctor. ${ }^{1,2}$ He studied medicine at the Pepiniere Institute in Berlin, graduating in 1843. Subsequently, he worked as a surgeon and prosector (dissector for anatomical demonstration) at the Charité hospital in the same city, entering the field of basic experimental chemistry and medical microbiology under the guidance of his tutors, Johannes Müller (1801-1858) and Lukas Schönlein (1793-1864). ${ }^{1,4}$

Virchow described processes of cytogenesis in his doctoral thesis entitled "De rheumate praesertim corneae" (1843) supervised by Müller himself after reviewing the work of Theodor Schwann, "Microscopic investigations on the coincidence of animals and plants in structure and growth", thus continuing the thesis of conceiving the cell as the functional unit of every living being. ${ }^{2,3}$ His early research was oriented towards the description of vascular inflammatory models, coining for the first time classic concepts within medical terminology, such as embolism and thrombosis to describe the microscopic phenomena prior to the establishment of phlebitis, while he was also interested in the immunological role of leukocytes in the face of any exogenous noxa on the endothelium, defining the terms chemotaxis and diapedesis., ${ }^{4,5}$

\section{Political and social activity}

It was clear to Virchow that medicine had a social function that could not be postponed. By 1848 he was delegated as a study committee member following a typhus epidemic in Silesia (now Poland) a year earlier, documenting sufficient evidence to demonstrate that poor health conditions were a reflection of the absence of state public policy and poor hygiene habits within the population, arguing that only the welfare, freedom and instruction of communities could reverse this scenario. ${ }^{6-9}$ In the same year he took an active part in the German revolution of 1848 (a wave that spread to other European cities and called for greater political freedom); the insurrection was quickly suppressed by the government and Virchow began to be recognised as a prominent leader within the opposition. ${ }^{10}$ His social sense of medicine earned him many detractors, and he decided to retire from his work in Berlin and settle in Würzburg (Bavaria) as an assistant professor of pathological anatomy. This was a period of intense intellectual production for Virchow. ${ }^{1,6}$

In 1856 he returned to Berlin, founding the Prussian Workers' Party, and was admitted to the Prussian parliament a year later. By this time, he was in frequent political correspondence with Otto von Bismarck regarding the military budget and public policy. At the same time, Virchow collaborated in the famous excavation of Troy together with archaeologist Heinrich Schliemann. These were the beginnings of social and cultural anthropology, consolidated after the founding of the German Anthropological Society in 1869 . $^{7}$ His intense political activity within his medical practice was quite prolific, and he was a forerunner of sanitary reforms, including the construction of the Berlin sewerage system in 1873, the design of which he learned in Paris, under the advice of Napoleon III, in 1867. ${ }^{6,7}$ His liberal ideas led to several advances on different fronts: a tax reform, regulation of self-government and the sponsoring of various public (economic and social) policies, which helped to modernise the stagnant feudal state from which the state institutions of the time were administered in Germany. ${ }^{1,7}$

\section{Fundamentals of clinical pathology}

Virchow's research focused on tumour and bone pathology, inflammation and tuberculosis, phlebitis, coagulation, fibrin and thrombosis. In his view, the inflammatory response was the basis of pathology and corresponded to tumour cell injury originating from nutritional or trophic disturbances and not only as a product of vascular and/or nervous influxes. On the basis of his observations, he developed a lexicography still in use today in pathological anatomy, with terms such as fatty degeneration, conjunctiva, tuberculous and caseous degeneration, parenchymal inflammation, embolism, leukaemia, amyloid degeneration. ${ }^{8}$ Together with other physicians, he founded the famous journal "Archiv fur Pathologische Anatomie und Physiologie und fur Klinische Medizin" (Archives of Pathological Anatomy and Physiology for Clinical Medicine) in 1846, an academic space where advances in the areas of basic biomedical sciences were presented, and remained as editor from the publication of the first volume in 1847 until his death. Today, the journal is preserved under the name "Virchow Archives". ${ }^{9}$ Figure 1 shows one of the first issues of the journal.

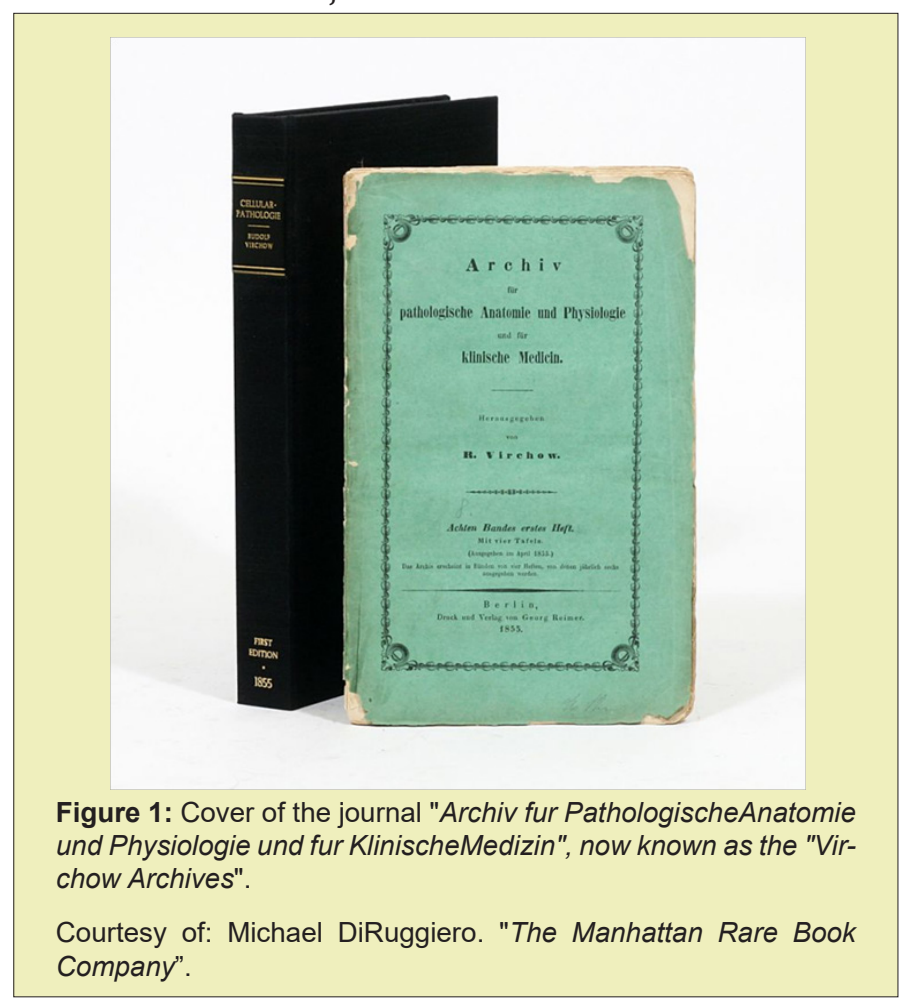


In 1858, after the death of Professor Hemsbach, Virchow was appointed professor of pathology at the Humboldt University in Berlin. In the same year, he published his influential work consisting of 20 articles, entitled "Die Cellularpathologie in ihrer Begründung auf physiologische und pathologische Gewebenlehre" (Cellular pathology in ihrer Begründung auf physiologische und pathologische Gewebenlehre), which was a paradigmatic revolution in the international scientific community. He was also among the first scientists to routinely implement the optical microscope for the study of tissues, promoting through this practice his famous aphorism "Omniscellula e cellula": (every cell comes from every other cell), a term that recognised the continuity of the cell theory initiated by Schwann. After this, the number of professorships devoted to the subject increased in both Germany and Austria., ${ }^{1,8}$

Virchow's colossal work was continued by his disciples, renowned pathologists of the time, such as Carl Gegenbaur, Ernst Haeckel, Adolf Kussmaul, Hugo von Ziemssen, Carl Gerhardt, Theodor Edwin Klebs, Georg Rindfleisch, Julius Cohnheim and Friedrich von Recklinghausen $(8,10)$. He is presumed to have advised William Welch and Sir William Osler, two of the "big four of Johns Hopkins Hospital", founders of its famous School of Medicine. ${ }^{11}$ He also made contributions in the field of experimental oncology. ${ }^{12}$ In 1863, after years of studying inflammation-related processes from stromal injury, he linked the development of cancer to chronic inflammation, suggesting that the latter was a potential substrate for oncogenesis by inducing changes in cell differentiation. Balkwill and Mantovani, ${ }^{13}$ in their article entitled "Inflammation and cancer: back to Virchow", presented an ingenious metaphor that summarises the main idea of this approach: "If genetic damage is the match that lights the fire of cancer, inflammation provides the fuel that feeds the flames"; translated: "If genetic damage is the match that lights the fire of cancer, inflammation provides the fuel that feeds the flames". This, of course, does not take into account the genetic predisposition component and somatic mutations that account for the development of some tumours. ${ }^{12,14}$

Even Theodor Billroth (1829-1894), the famous German surgeon, was firmly convinced of the importance of anatomopathological studies, after learning of Virchow's work on the origin of tumour cells and the ability to differentiate neoplastic processes from benign ones by means of microscopic analysis, which gave rise to surgical pathology. ${ }^{6,15}$ For Laín-Entralgo, a renowned historian of medicine, Virchow built cellular pathology on a "general theory of disease based on three principles: 1) the principle of localisation: there are no "general diseases"; every morbid process is anatomically localised; 2) the principle of cellular lesion: if one wants to know what in disease is truly fundamental, one must have recourse to the study of the cell; 3 ) principle of danger: the life of the diseased cell carries within it a certain idea of "danger", and this is what basically distinguishes disease from health in terms of modes of life. ${ }^{15}$

\section{Contributions to internal medicine}

Virchow is considered the pioneer of pathological anatomy. Through his legacy, he advocated that research should be construct- ed by the physicians themselves on the basis of their own clinical observations and the development of complementary animal experiments. ${ }^{11,16}$ Throughout this process, several postulates were left as his legacy after his time at the Charité University Hospital in Berlin (Germany), where he described several fundamental facts for modern internal medicine. Some of these are listed below:

\section{Virchow triad}

In 1856, he was the first to propose the model of venous thromboembolism, from the genesis of deep vein thrombosis in the lower limbs and pelvic circulation and the subsequent development of acute pulmonary embolism. He also classified several types of thrombosis according to the context in which they occurred, into "compression-induced, neonatal and dilatational". ${ }^{16}$ This pathophysiological model is still valid today, despite the passage of time, and is explained by the influence of three converging processes in thrombogenesis: firstly, endothelial damage, i.e. damage to the endothelium after which the basement membrane is exposed, with subsequent platelet adhesion and release of local vasoactive substances, favouring the formation of a black thrombus by apposition. Secondly, slowing of blood flow or blood stasis, i.e. slowing of flow within the vessel in the context of different conditions that alter blood rheology (heart failure, mitral stenosis, AHT, chronic venous insufficiency, advanced age, obesity, cancer, pregnancy, hormone therapy and prolonged immobility) leading to the formation of a red thrombus by an activation mechanism similar to secondary haemostasis. Finally, the establishment of an inherited or acquired state of hypercoagulability, which will favour the presence of microthrombi in the venous and/or arterial circulation. ${ }^{16,17}$ Although he understood haemostasis as a natural process, he considered that thrombus formation was stimulated by at least one of the previously noted factors.

\section{Virchow's ganglion}

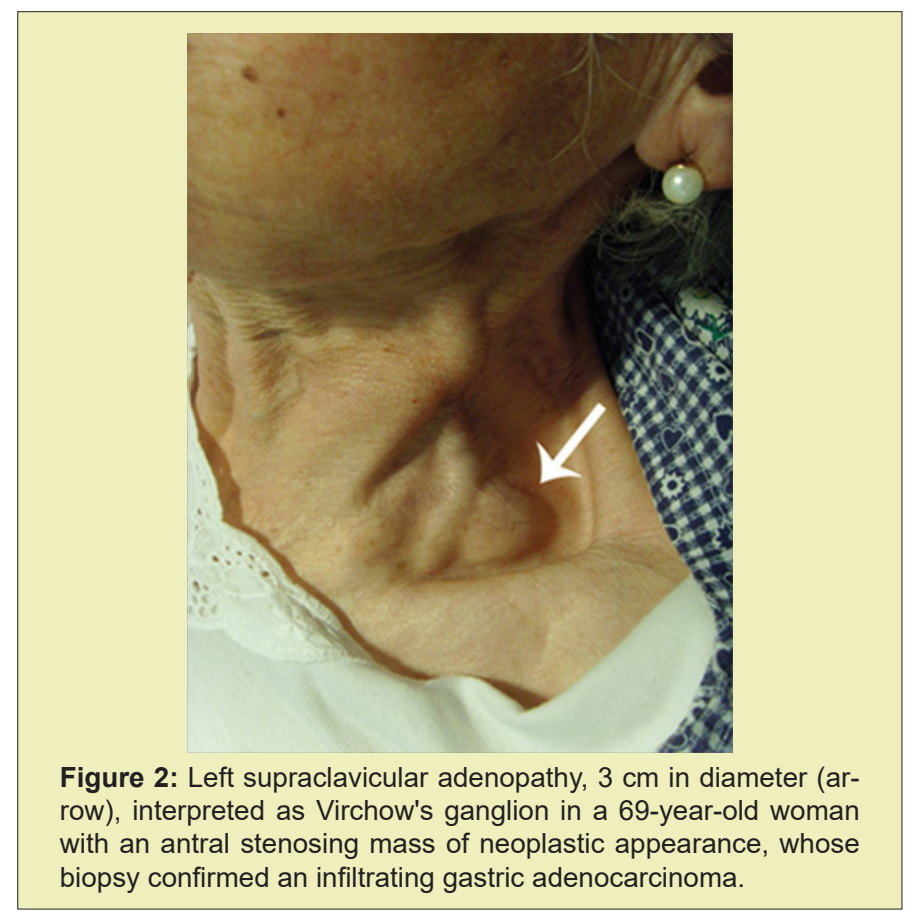


It is an enlarged lymph node (larger than $1 \mathrm{~cm}$ ), with a stony consistency, painless on palpation, in the left supraclavicular region, just at the point where the lymphatic vessels that drain a large part of the abdominal cavity converge, at the level of the thoracic duct, parallel to the venous circulation provided by the left subclavian vein. Classically, it has been related to gastric cancer (as proposed by Virchow in 1848), although its relationship with other solid tumours has been described, as proposed by the French pathologist Charles Émile Troisier, who in 1889 noted that other types of neoplasms (colon, pancreas, ovary and even breast) could also cause the appearance of the clinically pathologically significant lymph node. ${ }^{18,19}$ Figure 2 shows the finding of Virchow's lymph node in an oncology patient. This phenomenon occurs not only due to lymphangitic spread of tumour cells, but also due to blockage and stasis of lymphatic capillaries from the site of tumour progression in situ in the abdomen. ${ }^{20,21}$

\section{Selected topics in haematology}

Virchow was the first to assign the term leukaemia, meaning

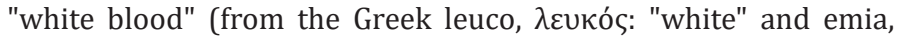

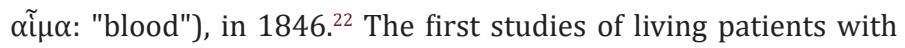
leukaemia were carried out in 1845 by three researchers of the time: Virchow in Germany was the first to propose that the problem was not infectious but a different pathology affecting certain organs. Bennett and Craige in Scotland also recognised the condition as a white blood cell problem, after presenting the necropsy report of a 28-year-old man who died without clear cause, describing "hypertrophy of the spleen and liver associated with suppuration of the blood", in the absence of pathogenic microorganisms in tissue samples. It was concluded that "all his blood was compromised, presenting a transformation within his blood system towards excess of granulocytic lineage formative elements". ${ }^{23}$ These findings were published by Bennett in the Edinburgh Medical and Surgical Journal, paving the way for the study of acute leukaemias as separate entities. ${ }^{23,24}$ On the other hand, the term "amyloid" (equivalent to starch or cellulose) was introduced by Virchow in 1854, when he observed that amyloid deposits had the same behaviour as cellulose in staining with iodine and sulphuric acid. Similarly, Friederich and Kekulé discovered its protein nature a few years later, but it was not until 1922 that its affinity to Congo red staining (congophilia) was observed. ${ }^{25}$ This marked the first advances in the understanding of amyloidosis, a multisystemic disease with a variable genetic background, heterogeneous in its clinical presentation.

In 1859, Virchow undertook a trip to Norway at the invitation of the government to investigate an epidemic of leprosy (Hansen's disease) on the west coast of Norway, probably in the Bergen area. His contribution to the study of this infectious disease was his description of "Virchow cells", macrophages arranged in a loosely circumscribed manner in the dermis, with a few adjacent lymphocytes (sometimes none), distended by large clusters of leprosy bacilli (globi), which may also be present in large numbers in cutaneous nerves and in the endothelium of small and large vessels, with occasional lipid content as a consequence of lysosomal bacillary destruction. ${ }^{26}$ Some precepts within the study of modern pathological nomenclature, such as aplasia, hypertrophy, hyperplasia, metaplasia and agenesis, are also part of Virchow's studies. ${ }^{1,27}$

\section{Final years and death}

His deep interest in geology, palaeoanthropology and folklore accompanied him throughout his life, and he later ventured into archaeology. His contribution to the museums and art collections of Berlin is well known, after convincing the famous archaeologist Heinrich Schliemann, discoverer of Troy, to bring his archaeological pieces to this German city. ${ }^{28}$ Virchow considered Neanderthal man, discovered in 1856, to be a member of the modern species Homo sapiens, explaining his physical deformities as the product of rickets in childhood and degenerative arthritis in adulthood. Subsequent palaeogenetic research showed that Neanderthals share a common origin with modern humans. ${ }^{11,28}$

Another remarkable episode to recall in the last years of his life concerns his participation in the "Kulturkampf", a term he coined to describe the movement for the limitation of the power of the Catholic Church in Germany, in which he aligned himself for the first and last time with Otto von Bismarck. ${ }^{29,30}$ While Virchow in Germany was developing the new science of cellular pathology, Louis Pasteur in France was innovating in the field of bacteriology. Virchow questioned Pasteur's germ theory. He believed that the diseased tissue causing disease was the result of cellular decomposition and not precipitated by the invasion of a foreign micro-organism. Today we know that both Virchow and Pasteur were right from the scientific argumentation of their respective theories of disease causation, both being complementary to each other. ${ }^{31}$ Figure 3 shows a portrait of Virchow in 1892.

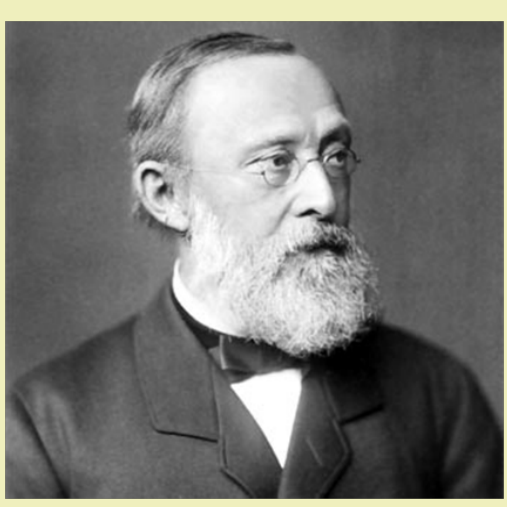

Figure 3: Rudolf Virchow, 1892.

During the Berlin winter of January 1902, he suffered a fall while trying to get out of an electric tram in Berlin, fracturing his right femur, from which he was never able to recover, and died in September of the same year. By that time, he had been nominated together with the Spanish Iberian scientist Santiago Ramón y Cajal for the Nobel Prize for Medicine and Physiology for the third time, but the prize finally went to the Spanish physician. . $32,33^{-3}$

\section{Conclusion}

Virchow was a staunch advocate of public health. His publications are full of proposals aimed at improving the economic and 
social determinants of health, understood from the point of view of disease prevention through the achievement of a real state of well-being on a large scale. He played this role to the full as a political activist while at the same time developing great advances in medical science, being considered one of the most visionary scientists of the $19^{\text {th }}$ century. Through this portrait of Rudolf Virchow, we wish to highlight the historical value of this type of personage, a source of inspiration for our professional practice, given that, as Hippocrates of Cos (460 BC - Thessaly c. 370 BC) pointed out, "Vita brevis, ars longa, occasio praeceps, experimentum periculosum, iudicium difficile" (34).Thessaly c. 370 BC), "Vita brevis, ars longa, occasio praeceps, experimentum periculosum, iudicium difficile", which translates: "Life is short, art, long; occasion, fleeting; experience, confused; judgement, difficult".

\section{Acknowledgments}

To the Faculty of Medicine of the University of Antioquia, for always inspiring from universal humanism.

Ethical responsibilities

The authors declare that no experiments on humans or animals have been carried out for this article. Due to its content, it does not merit an ethics committee review.

\section{Funding}

No funding was received.

\section{Conflicts of Interest}

None to be declared by the authors.

\section{References}

1. Dix Bastlein A. Rudolf Virchow: Wissenschaftliches Notizbuch 1843-1846: Kommentierte Uredition. Medizinische Fakultat Charite. Berlin: Universitätsmedizin; 2014. p. 33-52.

2. Mazana JS. Rudolph Virchow en el I centenario de su muerte. Anales de Medicina Interna. 2002;19(12):53-54.

3. Cortes García CM. La investigación social en salud: un punto de encuentro para las ciencias sociales y las ciencias de la salud. Revista de la Facultad de Medicina. 2010;58(4):259-262.

4. Maguina Vargas C, Gastelo Acosta R. Los maestros y sus discípulos a lo largo de la histo. Acta Médica Peruana. 2017;34(2):143-149.

5. Opal SM. A Brief History of Microbiology and Immunology. Vaccines: A Biography. 2009:31-56.

6. Scarani P. Rudolf Virchow (1821-1902). Virchows Arch. 2003;442(2): 95-98.

7. Walter E, Scott M. The life and work of Rudolf Virchow 1821-1902: “Cell theory, thrombosis and the sausage duel". Journal of the Intensive Care Society. 2017;18(3):234-235.

8. Drotman DP. Emerging infectious diseases: a brief biographical heritage. Emerg Infect Dis. 1998;4(3):372-373.

9. McFadden PM, Ochsner JL. A history of the diagnosis and treatment of venous thrombosis and pulmonary embolism. Ochsner J. 2002;4(1):913.

10. Lin JL. Rudolf Virchow: Creator of Cellular Pathology. Laboratory Medicine. 1983;14(12):791-794.

11. Schultz MG, Photo Quiz. Emerging Infectious Diseases. 2008;14(9):1479-1481.
12. Pasqualini CD. Oncología experimental: Volviendo a Boveri y Virchow. Medicina (Buenos Aires). 2012;72:530-532.

13. Balkwill F, Mantovani A. Inflammation and cancer: back to Virchow?. Lancet. 2001;357(9255):539-545.

14. Pasqualini CD. Papel bivalente del sistema inmune en el crecimiento tumoral. Medicina (Buenos Aires). 2004;64:277-280.

15. Lips Castro W. Breve historia de las causas naturales de la enfermedad humana. Gac Med Mex. 2015;151(6):806-818.

16. Kushner A, West WP, Pillarisetty LS. Virchow Triad. In: StatPearls. Treasure Island (FL): StatPearls Publishing; 2019.

17. Kumar DR, Hanlin, E, Glurich I. et al. Virchow's contribution to the understanding of thrombosis and cellular biology. Clinical medicine \& research. 2010;8(3-4):168-172.

18. Zdilla MJ, Aldawood AM, Plata A. Troisier sign and Virchow node: the anatomy and pathology of pulmonary adenocarcinoma metastasis to a supraclavicularlymph node. Autopsy \& case reports. 2019;9(1):e2018053.

19. Viacava EP, Pack GT. Significance of supraclavicular signal node in patients with abdominal and thoracic cancer: a study of one hundred and twenty-two cases. Arch Surg. 1944;48(2):109-119.

20. Cortes A Claudio, de Grazia K Jose A. ¿Nódulo de Virchow o de Troisier?: vieja disputa entre la literatura médica de habla inglesa y habla francesa. Revista chilena de cirugia. 2014;66(2):114-115.

21. Cortés A, Claudio, de Grazia K, et al. Nódulo de Virchow o de Troisier?: vieja disputa entre la literatura médica de habla inglesa y habla francesa. Revista chilena de cirugía. 2014;66(2):114-115.

22. Ortiz-Hidalgo C. Notas sobre la historia de la leucemia. Patol Rev Latinoam. 2013;51(1):58-69.

23. Piller G. Leukaemia-a brief historical review from ancient times to 1950. Br J Haematol. 2001;112(2):282-292.

24. Thomas X. First contributors in the history of leukemia. World $J$ Hematol. 2013;2(3):62-70.

25. Sipe JD, Cohen AS. Review: history of the amyloid fibril. J Struct Biol. 2000;130(2-3):88-98.

26. Rodríguez G, Arias V. Giant cells lepromatous leprosy. Diffuse dermatitis with exuberant foreign body giant cells in treated lepromatous leprosy. Biomedica. 2019;39(Supl. 2):26-31.

27. Brown TM, Fee E. Rudolf Carl Virchow: medical scientist, social reformer, role model. American journal of public health. 2006;96(12):2104-2105.

28. Zimmerman A. Anti-Semitism as Skill: Rudolf Virchow's Schulstatistik and the Racial Composition of Germany. Central European History. 1999;32(4):409-429.

29. Eisenberg L. Rudolf Virchow: The physician as politician. Medicine and War. 1986;2:4(243-250).

30. Taylor R, Rieger A. Medicine as social science: Rudolf Virchow on the typhus epidemic in Upper Silesia. International Journal of Health Services: Planning, Administration, Evaluation. 1985;15(4):547-559.

31. Korniluk A, Koper O, Kemona H, et al. From inflammation to cancer. Irish journal of medical science. 2017;186(1):57-62.

32. Ruiza M, Fernández T, Tamaro E. Biografía de Rudolf Virchow. Barcelona: España, 2004.

33. Parquet RA. Rudolf Carl Virchow. Acta Gastroenterológica Latinoamericana. 2014;44(3):202.

34. Davies P. The crowded consultation. Br J Gen Pract. 2012;62(605):648649. 